\title{
Distinct patterns of pigment development underlie convergent hyperpigmentation between nocturnal and diurnal geckos (Squamata: Gekkota)
}

\author{
Aaron H. Griffing ${ }^{1}$, Tony Gamble $e^{1,2,3}$ and Aaron M. Bauer ${ }^{4^{*}}$
}

\begin{abstract}
Background: Evolutionary transitions in temporal niche necessitates specialized morphology, physiology, and behaviors. Diurnal, heliothermic squamates (lizards and snakes) that bask require protection from ultraviolet radiation (UV) that can damage internal organs such as the brain, viscera, and gonads. Many smaller squamates have accomplished this protection by hyperpigmentation of the peritoneum and subcutaneous dorsum. Typically, nocturnal species do not require these protections from ultraviolet light. However, some nocturnal species that exhibit extreme crypsis may be exposed to sunlight and UV and require some means of mediating that damage. One such species is Gekko (Ptychozoon) kuhli, a nocturnal, arboreal gecko that uses extreme crypsis to blend in with tree bark. Hiding motionless on tree trunks leaves geckos exposed to sunlight during the day. Thus, we predict that G. kuhli will have independently evolved a hyperpigmented phenotype. To investigate this hypothesized association between temporal niche, behavior, and morphology, we characterized adult subcutaneous pigment for eight gecko species and embryonic pigment accumulation for a subset of four of these species, exhibiting diverse temporal niche and thermoregulatory behaviors. We predicted that nocturnal/potentially-heliothermic G. kuhli would exhibit hyperpigmentation of internal structures like that of diurnal/heliothermic geckos. We further predicted that embryonic pigment accumulation of G. kuhli would resemble that of diurnal/heliothermic as opposed to nocturnal/ thigmothermic geckos.
\end{abstract}

Results: We found that temporal niche and thermoregulatory behavior predicted the degree of subcutaneous pigment in the eight gecko species examined. We demonstrate that G. kuhli accumulates pigment extremely early in embryonic development, unlike a diurnal/heliothermic gecko species, despite having a similar adult phenotype.

Conclusions: The evolution of hyperpigmentation in G. kuhli is likely an adaptation to limit damage from occasional daytime UV exposure caused by crypsis-associated basking behavior. Gekko kuhli achieves its hyperpigmented phenotype through a derived developmental pattern, not seen in any other lizard species investigated to date, suggesting novel temporal differences in the migration and/or differentiation of reptilian neural crest derivatives.

Keywords: Crypsis, Embryology, Gekkonidae, Melanophore, Squamate, Temporal niche

\footnotetext{
* Correspondence: aaron.bauer@villanova.edu

${ }^{4}$ Department of Biology and Center for Biodiversity and Ecosystem

Stewardship, Villanova University, 800 Lancaster Avenue, Villanova, PA 19085,

USA

Full list of author information is available at the end of the article
}

(c) The Author(s). 2020 Open Access This article is licensed under a Creative Commons Attribution 4.0 International License, which permits use, sharing, adaptation, distribution and reproduction in any medium or format, as long as you give appropriate credit to the original author(s) and the source, provide a link to the Creative Commons licence, and indicate if changes were made. The images or other third party material in this article are included in the article's Creative Commons licence, unless indicated otherwise in a credit line to the material. If material is not included in the article's Creative Commons licence and your intended use is not permitted by statutory regulation or exceeds the permitted use, you will need to obtain permission directly from the copyright holder. To view a copy of this licence, visit http://creativecommons.org/licenses/by/4.0/. The Creative Commons Public Domain Dedication waiver (http://creativecommons.org/publicdomain/zero/1.0/) applies to the data made available in this article, unless otherwise stated in a credit line to the data. 


\section{Background}

Temporal niche, also known as diel activity niche, is an important aspect of the biology of an organism, necessitating the evolution of specialized morphology, physiology, ecology, and behavior (e.g. [19, 41, 56, 72]). For example, many diurnal ectotherms thermoregulate through basking behavior (i.e. heliothermy), whereas nocturnal ectotherms thermoregulate through contact with surfaces of different temperatures (i.e. thigmothermy; $[1,16,51])$. Temporal niche appears to be phylogenetically conserved across major tetrapod clades [2] and thus many adaptations to specific temporal niches (diurnal, nocturnal, crepuscular, or cathemeral) are shared among closely related species. Despite its conservation in tetrapod evolutionary history [2], several squamate clades do exhibit temporal niche turnover. The crown group of geckos (Infraorder Gekkota) are hypothesized to be ancestrally nocturnal, with reversals to diurnality occurring in at least 10 lineages [2, 24, 76]. Many of these lineages exhibit an array of diurnalspecialized adaptations, most notably eye morphologies, with oil droplets which aid in light filtering and spectral tuning $[9,55,70,76]$, concaviclivate temporal fovea to aid in binocular vision [57, 71], and ovoid retinal pigmented epithelia (RPE) to aid in light filtering and absorption [31, 65].

Another phenotype that is typically correlated with diurnal temporal niche in vertebrates is the hyperpigmentation of internal structures, such as the overlaying connective tissues of the brain, gonads, subcutaneous dorsum, and peritoneum [13, 34, 39, 50]. These dense collections of melanophores are hypothesized to protect internal structures from injurious and mutagenic UV radiation, which heliotherms encounter more frequently than thigmotherms $[12,13,38,50,52]$. Though heliothermy is correlated with hyperpigmentation of internal structures, some gecko species exhibit a disconnect between thermoregulatory behavior and temporal niche. For example, Sphaerodactylus geckos (Sphaerodactylidae) are primarily diurnal, but are active underneath leaf-litter and are thus thigmothermic [33]. Alternatively, Strophurus geckos (Diplodactylidae) are primarily nocturnal, yet occasionally bask during daylight hours [25]. This "occasionally-heliothermic" classification is supported by Strophurus exhibiting hyperpigmented peritonea [25].

Parachute geckos (Subgenus Ptychozoon) of the genus Gekko comprise 12 described species which inhabit dipterocarp forests of southeast Asia [11, 32, 68, 81]. This clade is characterized, in part, by a suite of specialized traits, including expanded trunk folds, expanded caudolateral folds, and elaborate interdigital webbing, which allow for a gliding predator escape behavior [8]. Following Russell's [59] step-wise hypothesis, gliding behavior through these elaborate cutaneous folds was exapted from use of the folds to reduce shadows (i.e. cryptic behavior) and thus, in conjunction with cryptic coloration, conceal the animal from predators $[5,28-30,49,58,64$, 67, 73]. Though chiefly nocturnal, Gekko (Ptychozoon) kuhli can occasionally be found on exposed tree trunks and branches during the day [28-30, 66]. This is likely a byproduct of cryptic behavior, as remaining motionless on tree trunks and branches throughout the day may result in exposure to direct sunlight and suggests an occasionally-heliothermic thermoregulatory classification. As mentioned previously, prolonged exposure to direct sunlight necessitates adaptations to tolerate higher temperatures and increased UV. We therefore hypothesize that behavioral crypsis, as implemented by G. kuhli, can lead to occasional heliothermy and the correlated phenotypic changes despite exhibiting a nocturnal temporal niche. To further investigate this hypothesized association between temporal niche, behavior, and pigment phenotype, we qualitatively characterized subcutaneous (fascial, visceral, and peritoneal) pigment for eight gecko species exhibiting diverse temporal niche and thermoregulatory behaviors. We predicted that nocturnal/potentially-heliothermic G. kuhli would exhibit hyperpigmentation of internal structures like that of diurnal/heliothermic geckos. Furthermore, to characterize patterns of pigment accumulation through embryonic development, we examined embryos at various stages of development from four gecko species exhibiting all combinations of temporal niche and thermoregulatory character states. We predicted that embryonic pigment accumulation of G. kuhli should also resemble that of diurnal/heliothermic as opposed to nocturnal/thigmothermic geckos.

\section{Results}

Adult nocturnal/thigmothermic species exhibited no pigment on the subcutaneous dorsal fascial surface (Fig. 1). Of these five species, only Hemidactylus platyurus exhibits pigment on the inside of the body cavity - the gonadal serosa is lightly pigmented, the peritoneum is lightly pigmented, and the intestinal serosa is black (Fig. 2; Table 1). The only diurnal/ thigmothermic species, Sphaerodactylus leonardovaldesi, exhibits no pigment on the subcutaneous dorsal fascial surface, with the exception of a lightly pigmented area posterior to the parietals (Fig. 1). Internally, $S$. leonardovaldesi exhibits a lightly pigmented peritoneum and liver (Fig. 2; Table 1). The diurnal/ heliothermic Phelsuma laticauda exhibits a black subcutaneous dorsal fascia surface along the skull, through the parietal region and along the trunk, shifting from black to dark pigmentation near the pelvic region (Fig. 1). Internally, $P$. laticauda exhibits a 


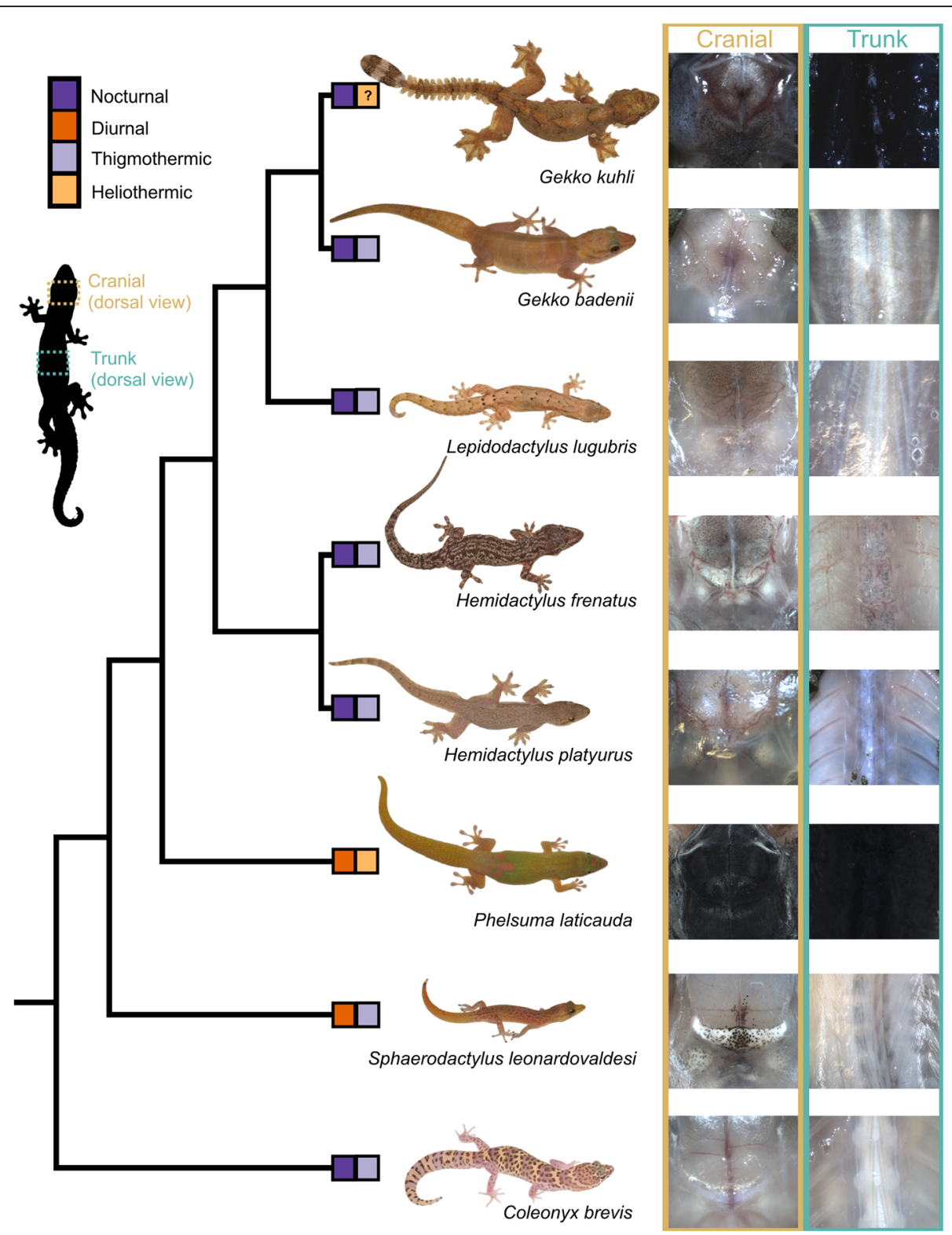

Fig. 1 Convergent evolution of subcutaneous dorsal hyperpigmentation in the geckos. Phylogenetic relationships of eight gekkotan taxa, exhibiting a variety of temporal niche and basking behavior character states, following the topology of Gamble et al. [24]. Dorsal views of the skinned parietal region (brown) and the mid trunk region (green) correspond to adjacent tips of the phylogeny. Gecko photographs: Stuart Nielsen

lightly pigmented liver, darkly pigmented gonadal serosa, both light and black areas of the peritoneum, and black intestinal serosa (Fig. 2; Table 1). Finally, the nocturnal/potentially-heliothermic Gekko kuhli exhibits a black subcutaneous dorsal fascial surface along the trunk and a darkly pigmented parietal region and remaining skull (Fig. 1). Internally, G. kuhli exhibits a lightly pigmented peritoneum and no pigment on the remaining viscera Fig. 2; (Table 1).

The first external pigment cells to accumulate in all gecko embryos are restricted to the RPE (Fig. 3 [31];).
Accumulation of melanophores, outside of the RPE, during embryonic development of G. kuhli begins shortly after oviposition Stage 29 (i.e. mid-limb bud stage; Fig. 3a,b). These initial sparse accumulations are located in the epidermis along the dorsum, outside of the developing optic tectum, and adjacent to the eye (Fig. 3a,b). At Stage 30, sparse melanophore accumulation spreads over the pharyngeal arches and the majority of the craniofacial region (Fig. 3a,b). By Stage 31, sparse accumulation has reached the forelimbs and the pigment accumulation along the 


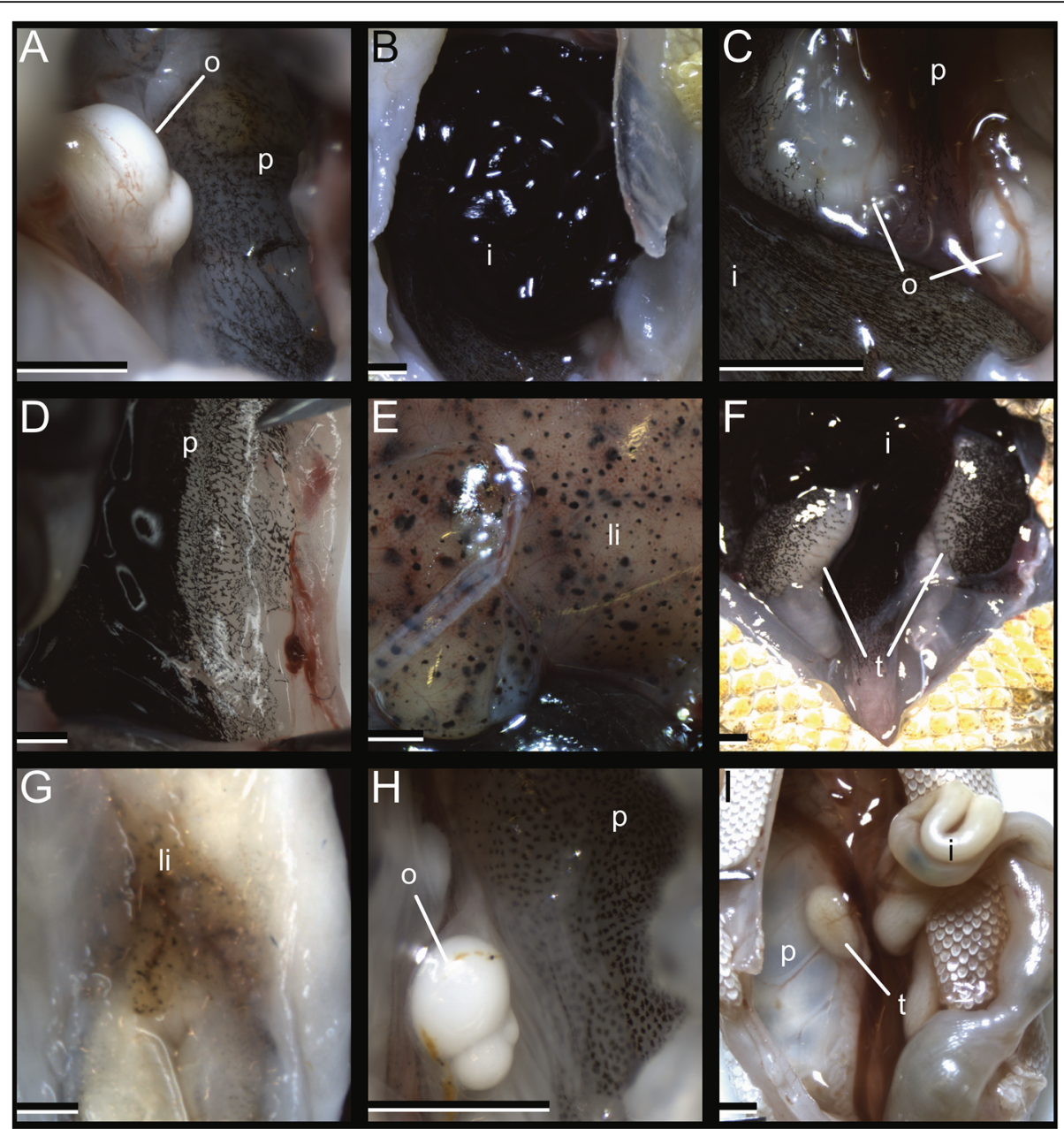

Fig. 2 Diversity of pigmented visceral serosae and peritonea in geckos. a ovaries and lightly pigmented peritoneum of G. kuhli. b Black intestines of H. platyurus. c Lightly pigmented ovaries and peritoneum of H. platyurus. d Black and lightly pigmented peritoneum of $P$. laticauda. e Lightly pigmented liver of P. laticauda. $\mathbf{f}$ Black intestines and darkly pigmented testes of P. laticauda. $\mathbf{g}$ Lightly pigmented liver of S. leonardovaldesi. $\mathbf{h}$ Ovaries and lightly pigmented peritoneum of $\mathrm{S}$. leonardovaldesi. i Completely unpigmented viscera and peritoneum of C. brevis which is identical to all other species investigated lacking internal melanophores. i, intestines; li, liver; o, ovaries; p, peritoneum; t, testes. Scale bars =1 mm

dorsum and craniofacial region is more dense (Fig. 3a,b). From Stage 31 to Stage 36, melanophore accumulation becomes denser and covers the entire surface of the embryo and begins to resemble the color pattern of near-hatchling G. kuhli: little pigment on the ventral surface, dense pigment on the dorsum creating faint chevron patterns, and dense pigment adjacent to the eye forming a dorsolateral stripe (Fig. 3a-c). By comparison, embryos of L. lugubris do not exhibit visible melanophores outside of the RPE during equivalent stages of development (Stages 2936; Fig. 3d-f). Indeed, regardless of temporal niche or basking behavior, all gecko embryos examined, with the exception of G. kuhli, lacked visible accumulation of pigment outside of the RPE until Stage 38-39 (Fig. 4). Sparse pigment accumulates along the center of the dorsum in Stage 38, and eventually spreads to the craniofacial region in Stage 39 (Fig. 4). During Stage 39, the pigment faintly resembles the eventual pattern of the near-hatchling animal and is colocalized with the epidermal papillae that will give rise to scales (i.e. Stage 42; Fig. 4).

\section{Discussion}

As predicted, G. kuhli exhibits darkly pigmented to black subcutaneous dorsal fascia while none of the other nocturnal gecko species examined exhibit dorsal fascia pigmentation (Fig. 1). As expected, and similar to G. kuhli, the diurnal/heliothermic gecko, P. laticauda, also exhibits black dorsal fascia pigmentation (Fig. 1). Furthermore, the diurnal/thigmothermic gecko, S. leonardovaldesi exhibits an intermediate phenotype: light dorsal fascia pigmentation near the braincase (Fig. 1). The only previous in-depth 
Table 1 Hyperpigmentation in geckos

\begin{tabular}{|c|c|c|c|c|}
\hline Species & $\begin{array}{l}\text { Temporal niche / thermoregulatory } \\
\text { behavior }\end{array}$ & $\begin{array}{l}\text { Fascial Pigment (Anterior, } \\
\text { Posterior) }\end{array}$ & $\begin{array}{l}\text { Peritoneal } \\
\text { Pigment }\end{array}$ & Visceral Pigment \\
\hline G. kuhli & $\mathrm{N} / \mathrm{H}$ & 2,3 & 1 & $\begin{array}{l}\text { liver (0), stomach/ intestines (0), } \\
\text { gonads (0) }\end{array}$ \\
\hline G. badenii & $\mathrm{N} / \mathrm{T}$ & 0,0 & 0 & $\begin{array}{l}\text { liver }(0) \text {, stomach/ intestines }(0) \text {, } \\
\text { gonads }(0)\end{array}$ \\
\hline L. lugubris & $\mathrm{N} / \mathrm{T}$ & 0,0 & 0 & $\begin{array}{l}\text { liver }(0) \text {, stomach/ intestines (0), } \\
\text { gonads (0) }\end{array}$ \\
\hline H. frenatus & $\mathrm{N} / \mathrm{T}$ & 0,0 & 0 & $\begin{array}{l}\text { liver }(0) \text {, stomach/ intestines }(0) \text {, } \\
\text { gonads }(0)\end{array}$ \\
\hline H. platyurus & $\mathrm{N} / \mathrm{T}$ & 0,0 & 1 & $\begin{array}{l}\text { liver (0), stomach/ intestines (3), } \\
\text { gonads ( } 1 \text { ) }\end{array}$ \\
\hline P. laticauda & $\mathrm{D} / \mathrm{H}$ & 3,3 & $1-3$ & $\begin{array}{l}\text { liver (1), stomach/ intestines (3), } \\
\text { gonads ( } 2 \text { ) }\end{array}$ \\
\hline $\begin{array}{l}\text { S. } \\
\text { leonardovaldesi }\end{array}$ & $\mathrm{D} / \mathrm{T}$ & 1,0 & 1 & $\begin{array}{l}\text { liver (1), stomach/ intestines (0), } \\
\text { gonads (0) }\end{array}$ \\
\hline C. brevis & $\mathrm{N} / \mathrm{T}$ & 0,0 & 0 & $\begin{array}{l}\text { liver (0), stomach/ intestines (0), } \\
\text { gonads ( } 0)\end{array}$ \\
\hline
\end{tabular}

Pigment levels are coded as follows: 0 , no melanophores or no pigment; 1 , scattered melanophores or lightly pigmented; 2 , many melanophores or darkly pigmented; and 3, opaque coating of melanophores or black. D, diurnal; $\mathrm{H}$, heliothermic; $\mathrm{N}$, nocturnal; $\mathrm{T}$, thigmothermic. Names of organs are listed with their associated serosal pigment level

investigations into gecko subcutaneous pigmentation was performed by Duncker [20-22], who examined 20 species. Duncker, who noted the extreme pigmentation of Phelsuma spp., also described fascial pigmentation in the largely nocturnal but often heliothermic Tarentola spp. [61] as well as pigmented nervous and vascular tissue of the largely nocturnal but heliothermic Ptyodactylus hasselquistii [3, 79]. The peritonea and the serosa of various visceral elements are pigmented in G. kuhli, P. laticauda, and $S$. leonardovaldesi. Duncker [21] reported pigmented intestine of G. kuhli, though we did not find this. There are multiple explanations for this discrepancy. First, Duncker's G. kuhli specimens may represent a different species from the G. kuhli specimens we examined, and G. kuhli, like many other species in the genus, may be a species complex comprised of multiple undescribed taxa $[11,17]$. Second, G. kuhli is a widespread species in Southeast Asia [11] and there may be intraspecific, regional variation. Interestingly, the gonads, intestines, and peritoneum of $H$. platyurus are pigmented. Hemidactylus platyurus, similar to G. $k u h l i$, is known to parachute, use elaborate body folds to aid in cryptic behavior, and is occasionally known to bask $[35,59,62,64,69]$, supporting the hypothesis that nocturnal geckos with cryptic diurnal behavior are exposed to ultraviolet radiation more frequently than other nocturnal gecko species and therefore require specialized protection. Indeed, the nocturnal and behaviorally cryptic, Uroplatus fimbriatus exhibits pigmentation in the digestive tract and the cloaca [77]. These hyperpigmented patterns represent similar evolutionary routes to protect the various internal delicate organs from UV and suggests species can take similar evolutionary paths to achieve similar functional goals in different structures [7, 44, 75]. When compared to G. kuhli, the lower degree of subcutaneous pigmentation exhibited by $H$. platyurus may be explained by behavioral differences between the species. Though $H$. platyurus is indeed behaviorally cryptic, anecdotal evidence suggests its behavioral crypsis is less effective than that of G. kuhli [64]. Taylor [66] noted that Gekko (Ptychozoon) lionotus can be reluctant to move from their cryptic positions and will flee only following "considerable disturbance, " whereas $H$. platyurus flee from similar positions with little disturbance [62]. Field observations also suggest that $H$. platyurus regularly use crevices in trees, rocks, gardens, and houses near human activity as day-time hiding locations ([10, 64, 66]; pers. observation in Philippines by AHG and TG) and are less likely to be exposed during the day compared to $G$. kuhli. This preliminary association between cryptic behavior and hyperpigmented phenotype, though promising, requires further corroboration through robust taxon sampling.

Vertebrate pigment cells are ultimately derived from neural crest cells, which begin migrating from the neural tube during the 6-9 somite stage in Chamaeleo calyptratus $[18,40]$. In avian reptiles and mammals, these unpigmented precursor cells migrate to the epidermis where mature melanocytes synthesize pigment which can then be deposited to epidermal appendages such as hair or feathers [63, 82]. 

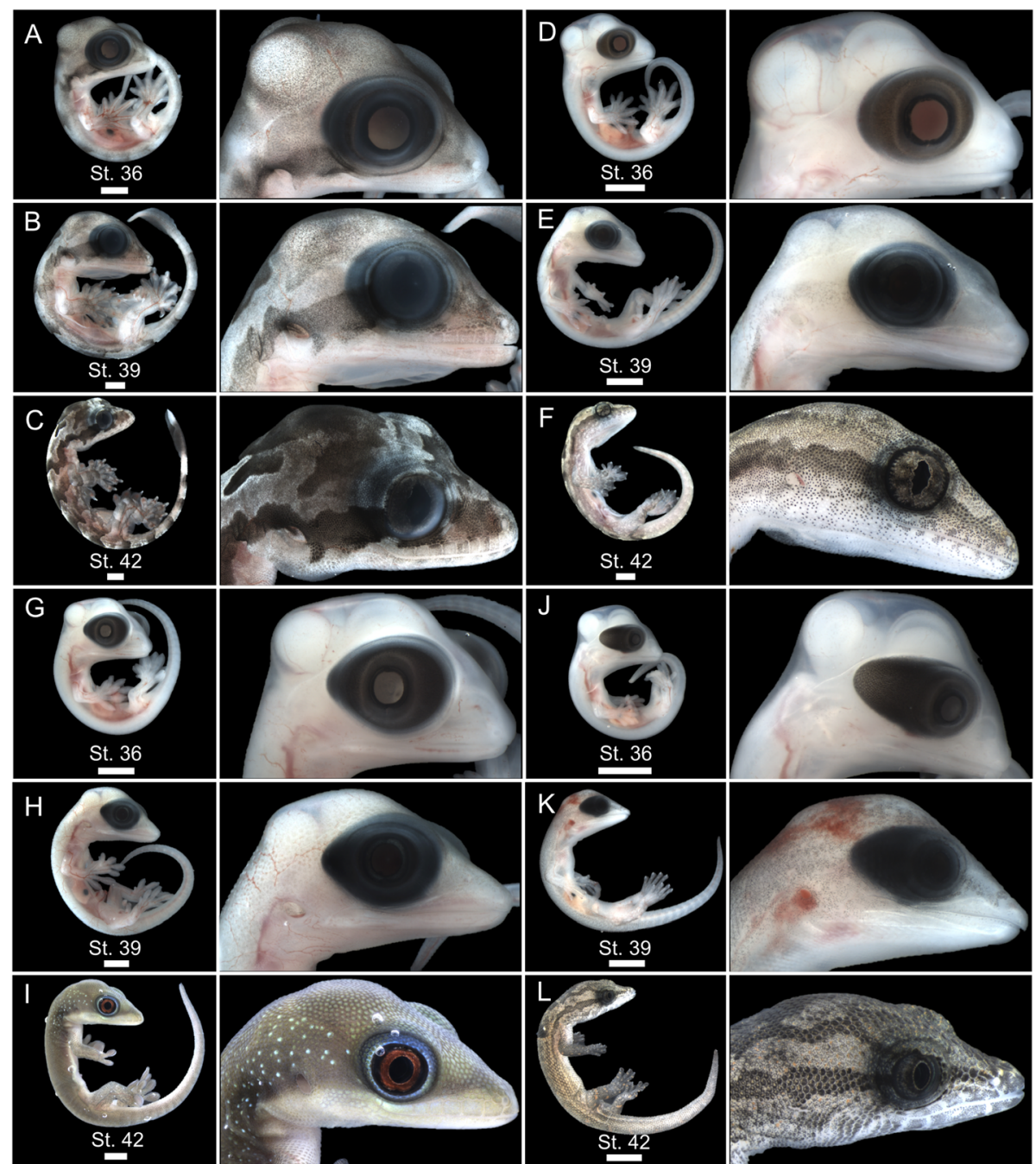

Fig. 3 Embryonic comparison between two nocturnal gekkonids: potentially heliothermic, cryptic Gekko kuhli and thigmothermic, non-cryptic Lepidodactylus lugubris. Note the early accumulation of dorsal and craniofacial pigment in G. kuhli while none is visible in L. lugubris. Row a Lateral view of whole G. kuhli embryos, stages 29-36. Row b Lateral view of G. kuhli embryos craniofacial region, stages 29-33. Row c Lateral view of G. kuhli embryos craniofacial region, stages 34-36. Row d Lateral view of whole L. lugubris embryos, stages 29-36. Row e Lateral view of L. lugubris embryos craniofacial region, stages 29-33. Row $\mathbf{f}$ Lateral view of L. lugubris embryos craniofacial region, stages $34-36$. White arrows indicate area of pigment accumulation. Scale bars $=2 \mathrm{~mm}$

Alternatively, non-avian reptiles, amphibians, and fishes produce three common types of chromatophores (xanthophores, iridophores, or melanophores) as well as more phylogenetically restricted pigment cell types (e.g. cyanophores, leucophores), for which developmental trajectories are still not well understood $[4,23,36,48]$. Despite this diversity, there is considerable conservation in molecular pathways responsible for melanocyte and chromatophore development $[15,47,48]$. The overall spatial pattern of pigment accumulation exhibited by G. kuhli appears similar the other gecko species examined - pigment accumulates along the epidermis overlaying the developing brain and the dorsum, adjacent to the anterior portion of the neural tube. However, the early onset temporal pattern of pigment development exhibited by G. kuhli has not been described in any other gecko species to date $[26,31,37,43,45,74,78,80$, 83], let alone other lizard species (e.g. [18, 42, 46, 53]). Heterochrony, specifically an early onset of melanophore migration, maturation, or pigment production, may explain the hyperpigmented adult phenotype of G. kuhli (Fig. 3). However, the same cannot be said for the hyperpigmented adult phenotype of $P$. laticauda or the intermediate pigmented phenotype of $S$. macrolepis (Fig. 4) highlighting how distinct developmental programs can lead to convergent phenotypes $[60,75]$. Further studies of squamate 

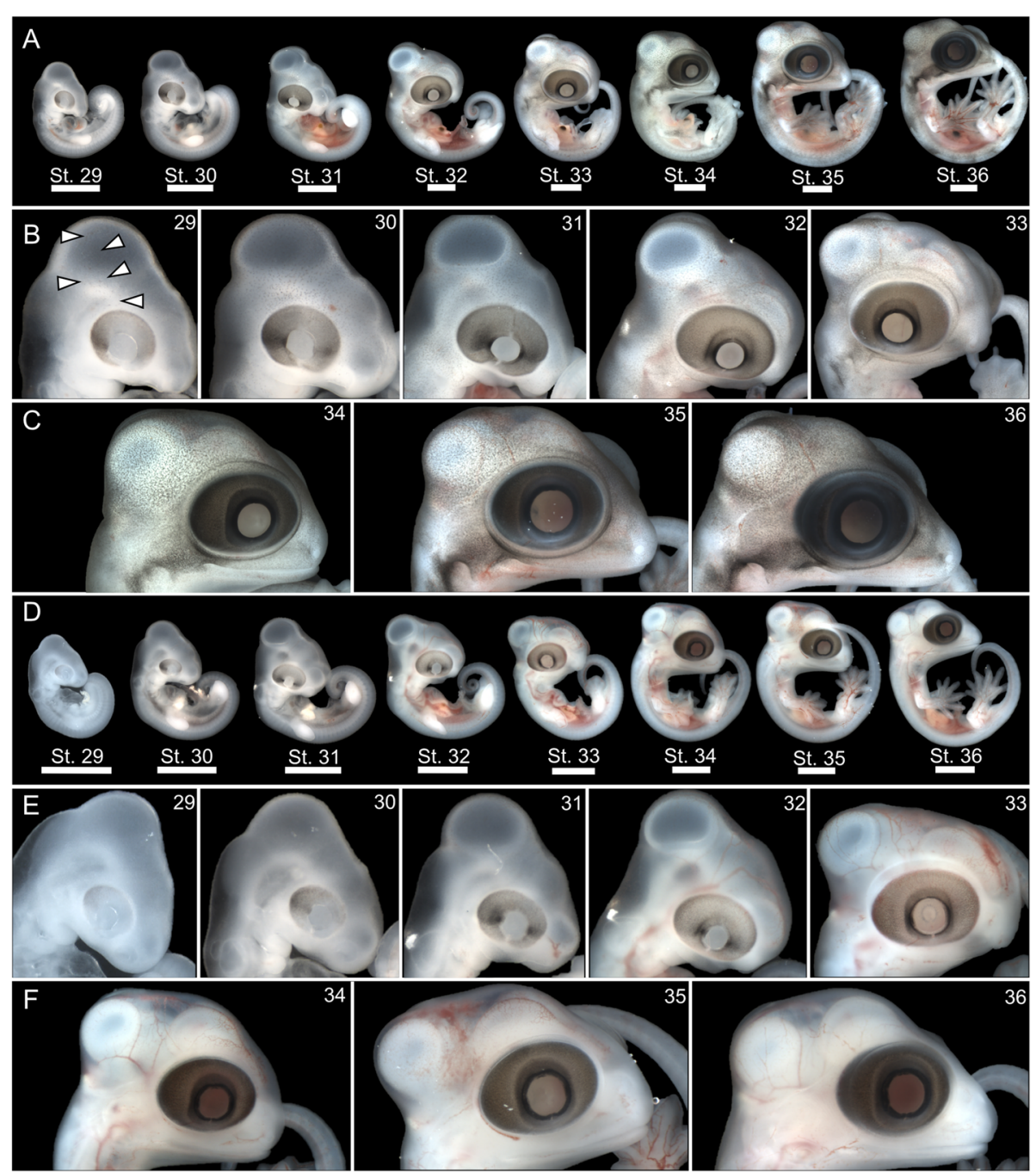

Fig. 4 Three embryonic stages of four gecko species showcasing lack of dorsal and craniofacial pigment (stage 36), early visible accumulation of dorsal and craniofacial pigment (stage 39), and near-hatching dorsal and craniofacial pigment (stage 42). Gekko kuhli stages 36 (a), 39 (b), and 42 (c). Lepidodactylus lugubris stages 36 (d), 39 (e), and 42 (f). Phelsuma laticauda stages 36 (g), 39 (h), and 42 (i). Sphaerodactylus macrolepis stages 36 (j), 39 (k), and 42 (I). Scale bars $=2 \mathrm{~mm}$

neural crest development are necessary to investigate interspecific variation in melanophore migration, specifically with regards to hyperpigmented peritonea or dorsal fascia $[18,54]$.

\section{Conclusions}

Herein we propose the hypothesis that behavioral crypsis can lead to situations which require heliothermic adaptation. Gekko kuhli, a nocturnal gliding gecko with behavioral crypsis, exhibits a degree of subcutaneous pigmentation that is typically only seen in diurnal/ heliothermic geckos such as Phelsuma spp. Another behaviorally cryptic, nocturnal gecko, $H$. platyurus, exhibits similar elaborate pigmentation on some viscera but not the dorsal fascia. Further investigations into this connection between thermoregulatory behavior and pigment phenotypes should test whether G. kuhli and H. platyurus can tolerate higher temperatures and are exposed to less ultraviolet damage than sister taxa with less pigment. Furthermore, G. kuhli appears to exhibit hyperpigmentation throughout most of postovipositional embryonic development, a developmental pattern which differs from other geckos, including heliothermic species. Due to this unique pattern, we suggest G. kuhli as a model to study temporal changes to typical reptilian patterns of neural crest derivative migration.

\section{Methods}

We qualitatively characterized subcutaneous (fascial, visceral, and peritoneal) pigment for six gekkonid gecko species exhibiting a diversity of temporal niche and thermoregulatory behaviors: Gekko kuhli (nocturnal/ 
potentially-heliothermic), Gekko badenii (nocturnal/thigmothermic), Lepidodactylus lugubris (nocturnal/thigmothermic), Hemidactylus frenatus (nocturnal/ thigmothermic), Hemidactylus platyurus (nocturnal/ thigmothermic), and Phelsuma laticauda (diurnal/ heliothermic). This taxon sampling allows us to compare dorsal fascial pigmentation of 3 of the 4 possible character state combinations and spanning the diversity of the Gekkonidae [24]. We also compare two outgroups: one sphaerodactylid (Sphaerodactylus leonardovaldesi) and one eublepharid (Coleonyx brevis) which exhibit diurnal/ thigmothermic and nocturnal/thigmothermic charter states, respectively. Each individual $(N=8)$ was euthanized humanely using MS222 following Conroy et al. [14], skinned and eviscerated to reveal subcutaneous pigment, and finally observed and photographed using a Nikon SMZ 74ST stereoscope. We characterized degree of pigmentation following Bauer [6]: no melanophores (no pigment), scattered melanophores present (lightly pigmented), many melanophores present (darkly pigmented), and complete opaque coating of melanophores present (black).

We collected eggs from captive colonies of four gecko species exhibiting all combinations of character states to observe embryonic patterns of pigment development: 49 embryos of G. kuhli (nocturnal/potentially-heliothermic), 141 embryos of L. lugubris (nocturnal/thigmothermic), 13 embryos of $P$. laticauda (diurnal/heliothermic), and 26 embryos of Sphaerodactylus macrolepis (diurnal/thigmothermic). Because embryos of S. leonardoveldesi were unavailable, we collected embryos of $S$. macrolepis as a congeneric proxy. We collected embryos $(N=229)$ following protocols described by Griffing et al. [27]. To briefly summarize, we removed embryos from eggs using \#5 watchmaker's forceps while immersed in diethyl pyrocarbonate (DEPC) treated, RNase free 1\% phosphatebuffered saline, and visualized and photographed using a Nikon SMZ 74ST stereoscope. As geckos exhibit interspecific variation between the precise time points (days post-oviposition; DPO) of developmental stages (Noro et al., 2009 [26, 37, 74, 80, 83];), we discretized and assigned developmental stages based on external morphology using previous embryonic staging series of geckos rather than characterizing by DPO $[26,80]$.

\section{Acknowledgements \\ We thank Tim Higham and Emily Naylor for providing additional Phelsuma laticauda. We also thank Eli Greenbaum, Shannon Keating, Rebecca Laver, Brendan Pinto, and Stuart Nielsen for assistance with fieldwork. Additional thanks to Stuart Nielsen, for the whole-body gecko photographs used in Fig. 1. We acknowledge the insightful comments of two anonymous re- viewers which benefitted an earlier version of this manuscript.}

\section{Authors' contributions}

AHG imaged all specimens. AHG and TG conceived and designed the study. AHG and AMB wrote the manuscript. All authors interpreted results. All authors read and approved the final manuscript.

\section{Funding}

Data collection, analysis, interpretation of data, and manuscript writing was made possible by funding through the National Science Foundation (NSF) DEB 1657662 awarded to TG and NSF DEB 1555968 awarded to AMB.

\section{Availability of data and materials}

The data (stereoscope images) supporting the results of this article are available in the FigShare repository, DOl: https://doi.org/10.6084/m9.figshare. 11914965, https://doi.org/10.6084/m9.figshare.11915001, https://doi.org/10. 6084/m9.figshare.11915007, and https://doi.org/10.6084/m9.figshare. 11915013.All specimens used in this study are housed at the Department of Biological Sciences, Marquette University (Milwaukee, Wisconsin).

\section{Ethics approval and consent to participate}

All work conducted at Marquette University as it relates to this study was done under approved Marquette University IACUC protocols (AR 279, AR 298, AR288). Marquette University has an AAALAC accredited Animal Care and Use Program and has the PHS Assurance on file with the Office of Laboratory Animal Welfare. All voucher specimens used in this study are stored at Marquette University (Milwaukee, WI USA). All animals, both fieldcollected and commercially obtained, were handled under Marquette University IACUC approved protocols (AR 279, AR 298, AR288). Individuals of G. kuhli, G. badenii, and H. platyurus used in this study and which produced embryonic material were acquired commercially. All other species were fieldcollected under the following collecting permits: C. brevis (Texas, 2018; SPR0590-067), H. frenatus (Hawaii, 2017; EX-18-02), L. lugubris (Hawaii, 2018; EX18-06), P. laticauda (Hawaii, 2018; EX-18-06), S. leonardovaldesi (Honduras, 2018; Resolución-DE-MP-213-2018), and S. macrolepis (Puerto Rico, 2017; 2016-IC-091).

\section{Consent for publication}

Not applicable.

\section{Competing interests}

The authors declare that they have no competing interests.

\section{Author details}

'Department of Biological Sciences, Marquette University, P.O. Box 1881, Milwaukee, WI 53201, USA. ²Milwaukee Public Museum, 800 W. Wells Street, Milwaukee, WI 53233, USA. ${ }^{3}$ Bell Museum of Natural History, University of Minnesota, Saint Paul, MN 55108, USA. ${ }^{4}$ Department of Biology and Center for Biodiversity and Ecosystem Stewardship, Villanova University, 800 Lancaster Avenue, Villanova, PA 19085, USA.

Received: 4 November 2019 Accepted: 18 March 2020

Published online: 27 March 2020

References

1. Adolph SC, Porter WP. Temperature, activity, and lizard life histories. Am Nat. 1993;142:273-95.

2. Anderson SR, Wiens JJ. Out of the dark: 350 million years of conservatism and evolution in diel activity patterns of vertebrates. Evolution. 2017;71: 1944-59.

3. Arad Z, Raber P, Werner YL. Selected body temperature in diurnal and nocturnal forms of Ptyodactylus (Reptilia: Gekkoninae) in a photothermal gradient. J Herpetol. 1989;23:103-8.

4. Bagnara JT, Taylor JD, Hadley ME. The dermal chromatophore unit. J Cell Biol. 1968;38:67-79.

5. Barbour T. A contribution to the zoogeography of the east Indian islands. Mem Mus Comp Zool. 1912;44:1-203.

6. Bauer AM. Peritoneal pigmentation and generic allocation in the Chamaeleonidae. Afr J Herpetol. 1997:46:117-23.

7. Blount ZD, Lenski RE, Losos JB. Contingency and determinism in evolution: Replaying life's tape. Science. 2018:362:eaam5979.

8. Boulenger GA. The Fauna of British India, including Ceylon and Burma. Reptilia and Batrachia. London: Taylor \& Francis; 1890.

9. Bowmaker J, Knowles A. The visual pigments and oil droplets of the chicken retina. Vis Res. 1977;17:755-64.

10. Brown CW, Alcala AC. Philippine lizards of the family Gekkonidae. Dumaguete City: Silliman University Press; 1978. 
11. Brown RM, Siler CD, Grismer LL, Das I, McGuire JA. Phylogeny and cryptic diversification in southeast Asian flying geckos. Mol Phylogenet Evol. 2012; 66:351-61

12. Cole LC. Experiments on toleration of high temperature in lizards with reference to adaptive coloration. Ecology. 1943;24:94-108.

13. Collette B. Correlations between ecology and morphology in anoline lizards from Havana, Cuba and southern Florida. Bull Mus Comp Zool. 1961;125: 137-62.

14. Conroy CJ, Papenfuss T, Parker J, Hahn NE. Use of Tricaine Methanesulfonate (MS222) for euthanasia of reptiles. J. Am. Assoc. lab. Anim. Sci. 2009:48:28-32

15. Cooper CD, Raible D. Mechanisms for reaching the differentiated state: insights from neural crested derived melanocytes. Semin Cell Dev Biol. 2008:20:105-10

16. Cowles RB, Bogert CM. A preliminary study of the thermal requirements of desert reptiles. Bull Am Mus Nat Hist. 1944;85:265-96.

17. Das I, Vijayakumar SP. New species of Ptychozoon (Sauria: Gekkonidae) from the Nicobar archipelago, Indian Ocean. Zootaxa. 2009;2095:8-20.

18. Diaz RE, Shylo NA, Roellig D, Bronner M, Trainor PA. Filling in the phylogenetic gaps: induction, migration, and differentiation of neural crest cells in a squamate reptile, the veiled chameleon (Chamaeleo calyptratus). Dev Dyn. 2019;248:709-27.

19. Duellman WE, Pianka ER. Biogeography of nocturnal insectivores: historical events and ecological filters. Ann Rev Ecol Syst. 1990;21:57-68.

20. Duncker H-R. Vereilungsmuster der Organpigmentierung bei Echsen (Sauria) und ihre entwicklungsgeschichtlichen Aspspekte. Verh Anat Ges Wien. 1965a;115:421-8.

21. Duncker H-R. Organpigmentierungen der Echsen (Sauria), dargestellt bei der Familie der Geckos (Gekkoniden). Verh. Anat. Ges. Wien. 1965b;115:469-70.

22. Duncker H-R. Die extracutanen Melanocyten der Echsen (Sauria). Ergeb Anat Entwicklungsgesch. 1968;40:1-55.

23. Fugii $\mathrm{R}$. The regulation of motile activity in fish chromatophores. Pigment Cell Res. 2000;13:300-19.

24. Gamble T, Greenbaum E, Jackman TR, Bauer AM. Into the light: diurnality has evolved multiple times in geckos. Biol J Linn Soc. 2015;115:896-910.

25. Greer AE. The biology and evolution of Australian lizards. Chipping Norton: Surrey Beatty \& Sons Pty; 1989.

26. Griffing AH, Sanger TJ, Daza JD, Nielsen SV, Pinto BJ, Stanley EL, Gamble T. Embryonic development of a parthenogenetic vertebrate, the mourning gecko (Lepidodactylus lugubris). Dev Dyn. 2019;248:1070-90.

27. Griffing AH, Sanger TJ, Matamoros IC, Nielsen SV, Gamble T. Protocols for husbandry and embryo collection of a parthenogenetic gecko, Lepidodactylus lugubris (Squamata: Gekkonidae). Herpetol Rev. 2018;49:2305 .

28. Grismer LL. Amphibians and reptiles of the Seribuat Archipelago, peninsular Malaysia. Frankfurt am Main: Edition Chimaira; 2011 a.

29. Grismer LL. Lizards of peninsular Malaysia, Singapore and their adjacent archipelagos. Frankfurt am Main: Edition Chimaira; $2011 \mathrm{~b}$

30. Grismer LL, Sukumaran J, Grismer JL, Youmans TM, Wood PL, Johnson R. Report on the herpetofauna of the Temengor Forest Reserve, Perak, West Malaysia. Hamadryad. 2004;29:15-32.

31. Guerra-Fuentes RA, Daza JD, Bauer AM. The embryology of the retinal pigmented epithelium in dwarf geckos (Gekkota: Sphaerodactylinae): a unique developmental pattern. BMC Dev Biol. 2014;14:29.

32. Heinicke MP, Greenbaum E, Jackman TR, Bauer AM. Evolution of gliding in southeast Asian geckos and other vertebrates is temporally congruent with dipterocarp forest development. Biol Lett. 2012;8:994-7.

33. Henderson RW, Powell R. Natural history of west Indian reptiles and amphibians. Gainesville: University of Florida Press; 2009.

34. Hill JE. A supposed adaptation against sunstroke in African diurnal rats. J Mammal. 1942;23:210.

35. Honda M, Hikida T, Araya K, Ota H, Nabjitabhata J, Hoi-Sen Y. Cosymbotus craspedotus (frilly gecko) and C. platyurus (flat-tailed gecko). Gliding behavior Herpetol Rev. 1997;28:42-3.

36. Kelsch RN. Genetics and evolution of pigment patterns in fish. Pigment Cell Res. 2004;17:326-426.

37. Khannoon ER. Developmental stages of the climbing gecko Tarentola annularis with specieal references to the claws, pad lamellae, and subdigital setae. J Exp Zool B. 2015;324:450-64.

38. Klauber LM. Studies of reptile life in the arid southwest. Bull Zool Soc San Diego. 1939;14:1-100.
39. Krüger $P$, Kern H. Die physikalische und physioloische Bedeutung des Pigmentes bei Amphibien und Reptilien. Pflügers Arch Gesamte Physio Menschen Tiere. 1924;202:119-38.

40. Le Douarin NM. The neural crest. Cambridge: Cambridge University Press; 1999.

41. Levy O, Dayan T, Kronfeld-Schor N, Porter WP. Biophysical modeling of the temporal niche: from first principles to the evolution of activity patterns. Am Nat. 2012;179:794-804

42. Lima FC, Py-Daniel TR, Sartori MR, Abe AS, dos Santos OP, Freitas LM, Pereira KF, Sebben A. Developmental staging table of the green iguana. Acta Zool. 2017:100:232-44

43. Mahendra BC. Contributions to the bionomics, anatomy, reproduction and development of the Indian house-gecko, Hemidactylus flaviviridis Rüppel. Part I Proc Indian Acad Sci B. 1936;4:250-81

44. Natarajan VT, Ganju P, Ramkumar A, Grover R, Gokhale RS. Multifaceted pathways protect human skin from UV radiation. Nat Chem Biol. 2014;10: 542-51.

45. Noro M, Uejima A, Abe G, Manabe M, Tamura K. Normal developmental stages of the Madagascar ground gecko Paroedura pictus with special reference to limb morphogenesis. Dev. Dynam. 2009;238:100-109.

46. Ollonen J, Da Silva FO, Mahlow K, Di-Poï N. Skull development, ossification pattern, an adult shape in the emerging lizard model organism Pogona vitticeps: a comparative analysis with other squamates. Front Physiol. 2018;9: 278.

47. Parichy DM, Spiewak JE. Origins of adult pigmentation: diversity in pigment stem cell lineages and implications for pattern evolution. Pigment Cell Melanoma Res. 2015;28:31-50.

48. Parichy DM, Reedy MV, Erickson CA. Regulation of melanoblast migration and differentiation. In: Nordland JJ, Boissy RE, Hearing VJ, King RA, Oetting WS, Ortonne J-P, editors. The pigmentary system: physiology and pathophysiology. 2nd ed. Oxford: Blackwell Publishing; 2006. p. 108-39.

49. Pong TY. Camouflage in the flying gecko, Ptychozoon kuhli Stejn. Malay Nat J. 1974;28:36.

50. Porter WP. Solar radiation through the living body walls of vertebrates with emphasis on desert reptiles. Ecol Monogr. 1967;37:273-96.

51. Pough FH, Gans C. Temperature regulation and thermal relations: the vocabulary of reptilian thermoregulation. In: Gans C, Pough FH, editors. Biology of the Reptilia, Volume 12, Physiology C. Physiological Ecology. London, New York, Paris, San Diego, San Francisco, São Paulo, Sydney, Tokyo, and Toronto: Academic Press; 1982. p. 17-23.

52. Pough FH, Kwiecinski G, Bemis W. Melanin deposits associated with the venom glands of snakes. J Morphol. 1978;155:63-72.

53. Py-Daniel TR, Lima AKS, Lima FC, Pic-Taylor A, Pires OR, Sebben A. A staging table of post-ovipositional development for the south American collared lizard Tropidurus torquatus (Squamata: Tropiduridae). Anat Rec. 2017:300: 277-90

54. Reyes M, Zandberg K, Desmawati I, de Bellard ME. Emergence and migration of trunk neural crest cells in a snake, the California kingsnake (Lampropeltis getula californiae). BMC Dev Biol. 2010;10:52.

55. Röll B. Characterization of retinal oil droplets in diurnal geckos (Reptilia, Gekkonidae). J Exp Zool. 2000;287:467-76.

56. Röll B. Multiple origin of diurnality in geckos: evidence from eye lens crystallins. Naturwissenschaften. 2001a;88:293-6.

57. Röll B. Gecko vision - retinal organization, foveae and implications for binocular vision. Vis Res. 2001b;41:2043-56.

58. de Rooij N. The reptiles of the indo-Australian archipelago, volume 1. Leiden: EJ Brill; 1915.

59. Russell AP. The origin of parachuting locomotion in gekkonid lizards (Reptilia: Gekkonidae). Zool J Linnean Soc. 1979;65:233-49.

60. Sanger TJ, Sherratt E, McGlothlin JW, Brodie ED III, Losos JB, Abzhanov A. Convergent evolution of sexual dimorphism in skull shape using distinct developmental strategies. Evolution. 2013;67:2180-93.

61. Schleich HH, Kästle W, Kabisch K. Amphibians and reptiles of North Africa. Koenigstein: Koeltz Scientific Publishers; 1996.

62. de Silva A, Madawala M, Bauer AM, Karunarathna S. Rediscovery of the frilled tail geck Hemidactylus platyurus (Schneider, 1792) in Sri Lanka after more than 160 years. J Threat Taxa. 2016;8:9663-6.

63. Slominski A, Wortsman J, Plonka PM, Schallreuter KU, Paus R, Tobin DJ. Hair and follicle pigmentation. J Investig Dermatol. 2005;124:13-21.

64. Smith MA. The Fauna of British India including Ceylon and Burma. Reptilia \& Amphibia, 2: Sauria. London: Taylor \& Francis; 1935. 
65. Strauss $\mathrm{O}$. The retinal pigment epithelium in visual function. Physiol Rev 2005;85:845-81.

66. Taylor EH. The lizards of Thailand. Univ Kansas Sci Bull. 1963;44:687-1077.

67. Tweedie MWF. The flying gecko, Ptychozoon kuhli Stejn. Proc Zool Soc Lond. 1950;120:13.

68. Uetz P, Freed P, Hošek J. The Reptile Database. 2019. Available at www. reptile-database.org. Accessed 5 Oct 2019.

69. Ulber T, Ulber E. Cosymbotus platyurus (Schneider). Sauria (Supp). 1991;13: 201-4.

70. Underwood G. Reptilian retinas. Nature. 1951;167:571-5.

71. Underwood G. The eye. In: Gans C, Prasons TS, editors. Biology of the Reptilia, volume 2, morphology B. London and New York: Academic Press; 1970. p. 1-97.

72. Valeix M, Chamaillé-Jammes S, Fritz H. Interference competition and temporal niche shifts: elephants and herbivore communities at waterholes. Oecologia. 2007;153:739-48.

73. Vetter RS, Brodie ED Jr. Background color selection and antipredator behavior of the flying gecko, Ptychozoon kuhli. Herpetologica. 1977;33:464-7.

74. Vos WVD, Stein K, Di-Poï N, Bickelmann C, Penner J. 2018. Ontogeny of Hemidactylus (Gekkota, Squamata) with emphasis on the limbs. Zoostyst. Evol. 2018;94:195-209.

75. Wake DB, Wake MH, Specht CD. Homoplasy: from detecting pattern to determining process and mechanism of evolution. Science. 2011;331:1032-5.

76. Walls $\mathrm{GL}$. The vertebrate eye and its adaptive radiation. Bloomfield: Cranbook Institute of Science, Cranbook Press; 1942.

77. Werner F. Beiträge zur Anatomie einiger seltenerer Reptilien, mit besonderer Berücksichtigung der Atmungsorgane. Arb Zool Inst Univ Wien. 1912;19: 373-424.

78. Werner YL. The ontogenetic development of the vertebrae in some gekkonoid lizards. J Morphol. 1971;133:41-92.

79. Werner YL, Goldblatt A. Body temperature in a basking gekkonid lizard, Ptyodactylus hasselquistii (Reptilia, Lacertilia, Gekkonidae). J Herpetol. 1978;12: 408-11.

80. Wise PAD, Vickaryous MK, Russell AP. An embryonic staging table for in ovo development of Eublepharis macularius, the leopard gecko. Anat Rec. 2009; 292:1198-212

81. Wood PL, Guo X, Travers SL, Su Y-C, Olson KV, Bauer AM, Grismer LL, Siler CD, Moyle RG, Andersen MJ, Brown RM. Parachute geckos free fall into synonymy: Gekko phylogeny, and a new subgeneric classification, inferred from thousands of ultraconserved elements. Mol Phylogenet Evol. 2020;146: 106731.

82. Yamaguchi Y, Brenner M, Hearing VJ. The regulation of skin pigmentation. J Biol Chem. 2007;282:27557-61.

83. Zhao R-N, Zhang L-Y, Wu PF, Ping J, Jin J-Y, Zhang YP. The morphological characteristics of embryos at different developmental stages in the Japanese gecko, Gekko japonicus. Chin J Zool. 2017;52:987-95.

\section{Publisher's Note}

Springer Nature remains neutral with regard to jurisdictional claims in published maps and institutional affiliations.

Ready to submit your research? Choose BMC and benefit from:

- fast, convenient online submission

- thorough peer review by experienced researchers in your field

- rapid publication on acceptance

- support for research data, including large and complex data types

- gold Open Access which fosters wider collaboration and increased citations

- maximum visibility for your research: over $100 \mathrm{M}$ website views per year

At $\mathrm{BMC}$, research is always in progress.

Learn more biomedcentral.com/submissions 